\title{
Effect of Plant Growth Regulators and Chemicals on Seed Germination, Vigour Index and Mortality of Avocado (Persea americana Mill.)
}

\author{
Nangialai Hakimi*, B. S. Shivakumar, D. Lakshmana, \\ M. Ganapathi and Nagarappja Adivappar
}

Department of fruit science, University of Agricultural and Horticultural sciences, Shivamogga, College of Horticulture, Mudigere-577-132, India

*Corresponding author

\begin{tabular}{|c|c|}
\hline & A B S T R A C T \\
\hline $\begin{array}{l}\text { K e y w o r d s } \\
\text { Avocado, Seed } \\
\text { germination, } \\
\mathrm{GA}_{3} \text {, Ethrel, } \\
\mathrm{KNO}_{3} \text {, Thiourea }\end{array}$ & \multirow{3}{*}{$\begin{array}{l}\text { Study on effect of plant growth regulators and chemicals on seed germination of } \\
\text { avocado (Persea americana Mill.) was carried out in college of Horticulture, } \\
\text { Mudigere, during the year 2019-2020, under Complete Randomized Design with } \\
\text { thirteen treatments and replicated thrice. Seeds were soaked in different solutions } \\
\text { of plant growth regulators and chemicals. Among all treatments seeds soaked in } \\
\mathrm{GA}_{3} 400 \mathrm{ppm} \text { recorded early germination ( } 13.00 \text { days), } 50 \text { per cent germination } \\
(19.33 \text { days), highest germination percentage }(95.22) \text {, maximum shoot length } \\
\text { ( } 75.67 \mathrm{~cm}) \text { and seedling vigour index-I and II ( } 9878.54 \text { and } 806.60 \text {, respectively). } \\
\text { Among all the treatments, } \mathrm{GA}_{3} 400 \mathrm{ppm} \text { was superior to the other treatments, } \\
\text { followed by } \mathrm{GA}_{3} 600 \mathrm{ppm} \text { for the enhancement of germination traits. }\end{array}$} \\
\hline Article Info & \\
\hline $\begin{array}{l}\text { Accepted: } \\
\text { 26 July } 2020 \\
\text { Available Online: } \\
10 \text { August } 2020\end{array}$ & \\
\hline
\end{tabular}

\section{Introduction}

Avocado (Persea americana Mill.) belong to family Lauraceae and it is native to the Central America and Southern Mexico, presently one of the most sought after food sources worldwide. Avocado is also called as Butter fruit for its buttery taste of pulp and gained importance over year as one of the most nutritive fruit. This fruit is also known by the name 'Alligator Pear' and 'fruit of new world (Radha and Mathew 2007). Butter fruit is rich in fat $(26.4 \mathrm{~g})$ and flesh of some varieties has twice the energy value of bananas. Fat is low in sugar content and easily digestible, hence it is a recommended fruit for diabetic patients. It contains one to two times more protein $(1.70 \mathrm{~g})$ than any other fruit, is rich in minerals such as manganese (35.00 $\mathrm{mg})$, phosphorous $(38.00 \mathrm{mg})$, iron $(0.60 \mathrm{mg})$ and potassium $(368.00 \mathrm{mg}$ ) but low in sodium (3.00 mg). Also contains the vitamins niacin (1.01 mg) vitamin $\mathrm{E}$, vitamin $\mathrm{C}$, B-carotene $(0.17 \mathrm{~g})$, thiamine $(0.06 \mathrm{mg})$, riboflavin $(0.13$ $\mathrm{mg}$ ), nicotinic acid, folate, total carbohydrates $(5.10 \mathrm{~g})$ and energy value of 245.00 calories (Rainey et al., 1994).The commercial avocado production is based on grafting of 
cultivars onto rootstocks mainly on the Mexican and Guatemalan races. In subtropical climates, the Guatemalan genotypes represent the dominant horticultural race. Avocado was brought to India during the first decade of the nineteenth century by an American missionary, residing in Bangalore between the years 1906 and 1914. In India it is growing in tropical and subtropical regions like Tamil Nadu, Sikkim, Kerala, Maharashtra and Karnataka. In India, avocado is generally propagated through seeds. The viability of seeds of avocado is quite short (2 to 3 weeks) but this can be improved by storage the seed in dry peat or sand at $50^{\circ} \mathrm{C}$. Removal of seed coat before sowing, use of plant growth regulators and chemicals improves seed germination. In India, most of the trees grown are seedlings in origin. The seeds taken from ripe fruits are sown directly in the nursery or in polyethylene bags, then 8-12 months old, the seedlings are ready for transplanting. The seedling trees have long juvenile phase, yield and fruit quality is highly variable due to heterozygous nature, it is impossible to obtain genetically uniform plant as needed for the formation of commercial orchards. Avocado is vegetatively propagating through various methods like softwood stem cuttings taken from young avocado seedlings, hardwood and semi-hardwood cuttings, layering, grafting and budding and there is a great demand for production of rootstock (Tripathi and Kuranakaran, 2013). Hence, the current study was undertaken to find out the effect of plant growth regulators and chemicals on seed germination of avocado.

\section{Materials and Methods}

The experiment was carried out at College of Horticulture, Mudigere during the year 20192020. It was laid out in Complete Randomized Design (CRD) thirteen treatments with three repetitions viz. water soaking as control $\left(\mathrm{T}_{1}\right), \mathrm{GA}_{3} 200 \mathrm{ppm}\left(\mathrm{T}_{2}\right)$, $\mathrm{GA}_{3} 400 \mathrm{ppm}\left(\mathrm{T}_{3}\right), \mathrm{GA}_{3} 600 \mathrm{ppm}\left(\mathrm{T}_{4}\right)$, ethrel $10 \mathrm{ppm}\left(\mathrm{T}_{5}\right)$,ethrel $20 \mathrm{ppm}\left(\mathrm{T}_{6}\right)$, ethrel 30 ppm $\left(\mathrm{T}_{7}\right), \mathrm{KNO}_{3} 1.0$ per cent $\left(\mathrm{T}_{8}\right), \mathrm{KNO}_{3} 1.5$ per cent $\left(\mathrm{T}_{9}\right), \mathrm{KNO}_{3} 2.0$ per cent $\left(\mathrm{T}_{10}\right)$, thiourea 1.0 per cent $\left(\mathrm{T}_{11}\right)$, thiourea 1.5 per cent $\left(\mathrm{T}_{12}\right)$ and thiourea 2.0 per cent. $\left(\mathrm{T}_{13}\right)$. For experiment purpose fresh and disease free seeds of avocado are collected and extracted and seeds soaked in different concentrations of $\mathrm{GA}_{3}$, ethrel, $\mathrm{KNO}_{3}$ and thiourea for 8 hours and seeds sown in polybags under the polytunnel. Polybags having a length of $15 \mathrm{~cm}$ and diameter of $10 \mathrm{~cm}$ with 200 gauge thickness were used and filled with soil + sand + FYM in the ratio of $1: 1: 1$, respectively. Treated seeds of avocado were sown in polybags of $20 \times 10 \mathrm{~cm}$ size filled in different mixture and its combinations on 28/09/2020. One seed per poly bag was sown at 5-10 $\mathrm{mm}$ depth. Watering was done regularly to maintain the uniform moisture. Necessary plant protection measures were taken. Five representative plants from each treatment were selected and observed for different germination parameters, growth characters and biochemical parameter. The experimental data recorded on various parameters during the investigation were analyzed statistically using the method of analysis of variance (ANOVA) for Complete Randomized Design (CRD) by Fisher and Yates (1963). Whenever ' $F$ ' test was found significant for comparing the means of two treatments, the critical difference (C.D. at 5\%) was worked out.

\section{Results and Discussion}

The data presented in Table 1 clearly shows that plant growth regulators and chemicals had significant influence on germination characters of avocado. Among the different treatments the earliest germination (13.00 days) was recorded significantly when seeds treated with $\mathrm{GA}_{3} 400\left(\mathrm{~T}_{3}\right)$ and maximum days taken for initiation of germination (20.67 
days) was recorded in control $\left(\mathrm{T}_{1}\right)$. The increase in germination due to involvement of gibberellic acid in the activation of cytological enzymes along with increase in cell wall plasticity and better water absorption.

Table.1 Effect plant growth regulators and chemicals on seed germination of avocado

\begin{tabular}{|c|c|c|c|c|c|c|}
\hline $\begin{array}{l}\text { Tr. } \\
\text { No. }\end{array}$ & Treatments & $\begin{array}{l}\text { Days taken for } \\
\text { initiation of } \\
\text { germination }\end{array}$ & $\begin{array}{l}\text { Days taken for } \\
50 \text { per cent } \\
\text { germination }\end{array}$ & $\begin{array}{l}\text { Germination } \\
\text { percentage } \\
\text { at } 45 \text { DAS }\end{array}$ & $\begin{array}{l}\text { Shoot } \\
\text { length } \\
\text { (cm) }\end{array}$ & $\begin{array}{c}\text { Mortality } \\
\text { percentage } \\
\text { at } 90 \text { DAS }\end{array}$ \\
\hline $\mathbf{T}_{1}$ & Water soaking (control) & 20.67 & 36.00 & 65.00 & 41.48 & 28.57 \\
\hline $\mathbf{T}_{2}$ & $\mathrm{GA}_{3} @ 200$ ppm & 15.33 & 23.67 & 85.22 & 58.20 & 7.14 \\
\hline $\mathbf{T}_{3}$ & $\mathrm{GA}_{3} @ 400 \mathrm{ppm}$ & 13.00 & 19.33 & 95.22 & 75.67 & 2.38 \\
\hline $\mathbf{T}_{4}$ & $\mathrm{GA}_{3} @ 600 \mathrm{ppm}$ & 13.33 & 20.33 & 91.17 & 68.83 & 4.76 \\
\hline $\mathbf{T}_{5}$ & Ethrel@10ppm & 15.33 & 27.00 & 81.00 & 57.89 & 11.90 \\
\hline$T_{6}$ & Ethrel@20 ppm & 15.00 & 23.33 & 90.00 & 58.70 & 9.52 \\
\hline $\mathbf{T}_{7}$ & Ethrel@30 ppm & 14.33 & 23.00 & 90.33 & 63.43 & 4.76 \\
\hline $\mathbf{T}_{8}$ & $\mathrm{KNO}_{3} @ 1.0 \%$ & 15.33 & 28.00 & 80.26 & 56.18 & 14.28 \\
\hline$T_{9}$ & $\mathrm{KNO}_{3} @ 1.5 \%$ & 16.67 & 30.67 & 76.28 & 53.98 & 19.04 \\
\hline $\mathbf{T}_{10}$ & $\mathrm{KNO}_{3} @ 2.0 \%$ & 17.67 & 31.33 & 74.26 & 45.81 & 14.25 \\
\hline$T_{11}$ & Thiourea@1.0\% & 15.67 & 29.67 & 78.00 & 55.42 & 16.66 \\
\hline$T_{12}$ & Thiourea@1.5\% & 17.00 & 31.00 & 75.00 & 52.76 & 23.80 \\
\hline $\mathbf{T}_{13}$ & Thiourea@2.0\% & 19.33 & 34.00 & 73.00 & 43.81 & 26.19 \\
\hline \multirow{2}{*}{\multicolumn{2}{|c|}{$\begin{array}{c}\text { S. Em } \pm \\
\text { C.D. @ 5\% }\end{array}$}} & 0.77 & 0.90 & 2.73 & 3.75 & 1.30 \\
\hline & & 2.24 & 2.61 & 7.95 & 10.90 & 3.79 \\
\hline
\end{tabular}

Table.2 Effect of plant growth regulators and chemicals on seedling vigour index I and II of avocado at 90 days after sowing

\begin{tabular}{|c|c|c|c|}
\hline Tr. No. & Treatments & Seedling index-I & Seedling index-II \\
\hline $\mathbf{T}_{\mathbf{1}}$ & Water soaking (control) & 3802.50 & 229.38 \\
\hline $\mathbf{T}_{\mathbf{2}}$ & $\mathrm{GA}_{3} @ 200 \mathrm{ppm}$ & 6834.64 & 459.61 \\
\hline $\mathbf{T}_{\mathbf{3}}$ & $\mathrm{GA}_{3} @ 400 \mathrm{ppm}$ & 9878.54 & 806.60 \\
\hline $\mathbf{T}_{\mathbf{4}}$ & $\mathrm{GA}_{3} @ 600 \mathrm{ppm}$ & 8677.36 & 569.25 \\
\hline $\mathbf{T}_{\mathbf{5}}$ & Ethrel @ $10 \mathrm{ppm}$ & 6394.77 & 429.91 \\
\hline $\mathbf{T}_{\mathbf{6}}$ & Ethrel @ 20 ppm & 7276.00 & 504.83 \\
\hline $\mathbf{T}_{\mathbf{7}}$ & Ethrel @ 30 ppm & 7970.11 & 522.54 \\
\hline $\mathbf{T}_{\mathbf{8}}$ & $\mathrm{KNO}_{3} @ 1.0 \%$ & 6182.69 & 405.58 \\
\hline $\mathbf{T}_{\mathbf{9}}$ & $\mathrm{KNO}_{3} @ 1.5 \%$ & 5569.29 & 340.52 \\
\hline $\mathbf{T}_{\mathbf{1 0}}$ & $\mathrm{KNO}_{3} @ 2.0 \%$ & 4698.18 & 310.59 \\
\hline $\mathbf{T}_{\mathbf{1 1}}$ & Thiourea @ $1.0 \%$ & 5941.87 & 367.72 \\
\hline $\mathbf{T}_{\mathbf{1 2}}$ & Thiourea @ $1.5 \%$ & 5325.00 & 317.34 \\
\hline $\mathbf{T}_{\mathbf{1 3}}$ & Thiourea @ 2.0\% & 4470.03 & 282.60 \\
\hline & S. $\mathbf{E m} \pm$ & $\mathbf{3 3 1 . 7 4}$ & $\mathbf{2 8 . 8 5}$ \\
\hline & C.D. $@ \mathbf{5} \%$ & $\mathbf{9 6 4 . 3 6}$ & $\mathbf{8 3 . 8 7}$ \\
\hline
\end{tabular}


It may be due to the fact that, $\mathrm{GA}_{3}$ impacts on initial enzyme stimulation and activation of reserve food mobilization intern improves germination. These findings are supported by Gupta (1989) in citrus, Ratan and Reddy (2004) in custard apple, Babu et al., (2010) in papaya and Satya et al., (2018) in jamun.

The minimum days to 50 per cent germination (19.33 days) was observed significantly with $\mathrm{GA}_{3} 400 \mathrm{ppm}\left(\mathrm{T}_{3}\right)$ while, the maximum days taken to 50 per cent germination was observed in control $\left(\mathrm{T}_{1}\right) . \mathrm{GA}_{3}$ helps in synthesis of $\alpha$ - amylase which converts the starch into simple sugars. These sugars provide energy that is required for various metabolic and physiological activities. Similar result was reported by Meena et al., (2003) in papaya. The findings of Venkatrao and Reddy (2005) in mango and Kumar et al., (2008) in mango, Satya et al., (2018) in jamun are close to the conformity of the findings.

The maximum germination percentage $(95.22$ $\%)$ was noted significantly when seed soaked in $\mathrm{GA}_{3} 400 \mathrm{ppm}\left(\mathrm{T}_{3}\right)$ whereas, the minimum germination percentage $(65 \%)$ was noted in control $\left(\mathrm{T}_{1}\right)$. The promotive effect of $\mathrm{GA}_{3}$ on seed germination might be due to enzyme $\alpha$ amylase is activated which converts starch into simple carbohydrate and chemical energy is released which intern activates embryo. Also might be due to, the production of amino acids in plants is enhanced, which is indirectly exhibited by improved growth of whole plant. The current findings is supported by Reddy and Khan (2001) in khirni, Jadhav (2003) in Rangpur lime, Sulabha and Kherdekar (2003) in Kagzi lime, Singh et al., (2011) in manila tamarind and Satya et al., (2018) in jamun.

The data in Table 1 shows that ethrel at concentrations of 20 and $30 \mathrm{ppm}$ i.e. $\mathrm{T}_{6}$ and $\mathrm{T}_{7}$ (90.00 and $90.33 \%$, respectively) also had significant effect on germination percentage of avocado after 45 days of sowing. Increased germination per cent with ethrel for 8 hours soaking period might be due to fact that ethrel being ethylene releasing compound, the localized production of ethylene is responsible for the initiation, formation and maintenance of either the plume arch, hypocotyl hook, depends on mode of germination. Ethylene is insoluble in water but soluble in lipids, therefore.it associated with lipid fraction of cell membrane and affects membrane structure permeability.

Significantly, the highest shoot length (75.67 $\mathrm{cm})$ of avocado seedlings was observed when seeds soaked in $\mathrm{GA}_{3} 400 \mathrm{ppm}\left(\mathrm{T}_{3}\right)$ which was statistically on par with $\mathrm{T}_{4}$ i.e. $\mathrm{GA}_{3} 600 \mathrm{ppm}$. Whereas, the lowest shoot length $(41.48 \mathrm{~cm})$ was noted in control $\left(T_{1}\right)$. This variation might be due to additional $\mathrm{GA}_{3}$, activated óamylase which digested the available carbohydrate into simple sugar so that energy and nutrition were easily available to faster growing seedlings. The increase in plant height due to $\mathrm{GA}_{3}$ has also been reported by Babu et al., (2010) in papaya. The similar, results was reported by Wanyama et al., (2006) in Cape gooseberry, Kumar et al., (2008) in mango, Mishra et al., (2017) in papaya and Satya et al., (2018) in jamun.

The data presented in Table 1 clearly indicates that growth regulators and chemicals had significant influence of mortality percentage of avocado seedlings at 90 days after sowing. Among the different treatments the least mortality percentage of seedling $(2.38 \%)$ was recorded significantly with $\mathrm{GA}_{3}$ $400 \mathrm{ppm}\left(\mathrm{T}_{3}\right)$, which was statistically on par with $\left(\mathrm{T}_{4}\right.$ and $\left.\mathrm{T}_{7}\right)$ and maximum mortality of seedling $(28.57 \%)$ was noted in control $\left(\mathrm{T}_{1}\right)$. This could be attributed to softening of seed for exchange of gaseous and moisture and availability of food material required for early and better germination in this treatment. Early germination might have resulted in faster and 
stronger root development, which might have supported for better development of stem and leaves in these seedlings, that might have resulted in increased in survival of seedlings. This might be also due to availability of favorable amount of light, temperature and humidity under poly-house or shade net condition, which makes the plants harder and able to withstand against adverse climatic conditions. The result has been supported by Ramteke et al., (2015) in papaya and Chiranjeevi et al., (2017) in aonla.

A perusal of data presented in Table 2 shows that plant growth regulators and chemicals shown significant influence of seedling vigour index I and II of avocado at 90 days after sowing. The maximum SVI-I (9878.54) was recorded significantly with $\mathrm{GA}_{3} 400 \mathrm{ppm}\left(\mathrm{T}_{3}\right)$ and the minimum SVI-I (3802.50) was recorded in control $\left(\mathrm{T}_{1}\right)$. Enzymes as well as physical and nutritional condition increased the physiological activities of plant. These finding are supported by Kumar et al., (2011) in papaya, Padma et al., (2013)in papaya, Gurung et al., (2014) in passion fruit and Satya et al., (2018) in jamun.

The maximum SVI-II (806.60) was noted in $\left(\mathrm{T}_{1}\right)$ i.e. $\mathrm{GA}_{3} 400 \mathrm{ppm}$ while, the minimum SVI-II was recorded in control $\left(\mathrm{T}_{1}\right)$. The maximum seedling vigour in $\mathrm{GA}_{3}$ treated seeds is an account of increased rate of metabolic activities like respiration, movement of photosynthates etc., (Earlplus and Lambeth, 1974), which leads to increase in root length, shoot size and seedling dry weight, in turn increase in seedling vigour. The results of Kumar et al., (2011) in papaya, Padma et al., (2013) in papaya, Gurung et al., (2014) in passion fruit and Satya et al., (2018) in jamun follow same trend.

In conclusion form the present investigation it is concluded that $\mathrm{GA}_{3} 400 \mathrm{ppm}\left(\mathrm{T}_{3}\right)$ enhanced the germination parameters, survival of seedling and increased the seedling vigour index of avocado followed by $\mathrm{GA}_{3} 600\left(\mathrm{~T}_{4}\right)$.

\section{References}

Babu, K. D., Patel, R, K., Singh, A., Yadav, D. S., De, L. C. and Deka, B. C., 2010. Seed germination, seedling growth and vigour of papaya under North East Indian condition. Acta Hort.851: 299306.

Chiranjeevi, M. R., Muralidhara, B. M., Senha, M. K., Shivan and Hongal, 2017. Effect of growth regulators and biofertilizers on germination and seedling growth of Aonla. Int. J. Curr. Microbi. App. Sci.6(12): 1320-1326.

Earlpus, E. J. R. and Lambeth, V. M.,1974. Chemical stimulation of germination rate in aged tomato seeds. J. Anzer. Sac. Horti. Sci. 99(1): 912.

Fisher, R. A. and Yates, F., 1963. Statistical tables for biological, medical and agricultural research. Oliver and Boyd Edinburgh. pp 86.

Gupta, O. P., 1989. Effect of gibberellic acid on seed germination in lime (Citrus aurantifolia Swingle.). Progressive Hort. 21: 3-4, 246-248.

Gurung, N., Swamy, G. S. K., Sarkar, S. K. andUbale, N. B., 2014. Effect of chemicals and growth regulators on germination, vigour and growth of passion fruit (Passiflora edulis Sims.). The Bioscan.9(1):155-157.

Jadhav, Y. S., 2003, Seed treatment studies in Rangpure lime. M.Sc. (Agri.). Thesis submitted to M.A.U, Parbhani.

Kumar, H. S., Swamy, Y., Kanmadi, G. S. K., Prasad, K. V. C. and Sowmaya, B. N., 2008. Effect of organics and chemicals on germination, growth and graft-take in mango. Asian J. Hort. 3(2): 336-339.

Kumar, P., Sehrawat, S. K., Dahiya, O. S. andDahiya, D. S., 2011. Papaya seed priming in relation to seed vigour. 
Haryana J. Horti. Sci. 40(1\&2):4-9.

Meena, R. R., Jain, M. C. and Mukherjee, S., 2003. Effect of pre-sowing dip seed treatment with gibberellic acid on germination and survivability of Papaya. Annals Plant and Soil Res. 5(1):120121.

Mishra, U., Bahadur, V., Prasad, V. M., Verty, P. S., Ashutosh, K., Mishra, S. and Swaroop, N., 2017. Influence of $\mathrm{GA}_{3}$ and growing media on growth and seedling establishment of papaya (Carica papaya L.) cv. PusaNanha. Int. J. Curr. Microbiol. App. Sci. 6(11): 415422.

Padma, L., Basvaraju, G. V., Sarika, G. andAmrutha, N., 2013. Effect of seed treatment to enhance seed quality of papaya (Carica papaya L.) cv. Surya. GJBAHS. 2(3): 221- 225.

Radha, T. and Mathew, L., 2007. Fruit Crops Book, Department of Fruit Science, Kerala Agriculture University. Hort. Sci. series.3: 130-130.

Rainey, C., Affleck, M., Bretschger, K. and Roslyn, A. S., 1994. The California avocado: A new look. Nutr. Today. 29:23-27.

Ramteke, V., Paithanker, D. H., Kamatyanattii, M. and Baghel, M. M., 2015. Studies on Seed germination and seedling growth of papaya as Influenced by $\mathrm{GA}_{3}$ and potting media, J. progressive Agri. 6(1): 129-123.

Ratan, P. B and Reddy, Y. N., 2004. Influence of gibberellic acid on custard apple $\begin{array}{lll}\text { (Annona squammosa } & \text { L.) seed }\end{array}$ germination and subsequent seedling growth. J. Res. ANGRAU. 32(2): 93-95.
Reddy, Y. T. N. and Khan, M. M., 2001. Effect of osmopriming on germination seedlings of khirni (Mimusops hexandra) seeds. Seed Res. 29(1): 2447.

Satya, N. H., Ajay, K. K., Jain, P. K. and Bharat, D., 2018. Effect gibberellic acid on germination, growth and survival of Jamun (Syzygium cumini L.). The Pharma Innovation J. 7(8): 323-326.

Singh, R. S., Bhargava, R. and Pal, G., 2011. Effect of seed treatments on germination and growth behaviour in Manila tamarind (Pithecello biumduice). J. Tropical Forestry. 27(4): 6-10.

Sulabha Kherdekar., 2003. Effect of seed treatment with plant growth regulators and chemicals on germination of seed and growth of seedling of Kagzi lime (Citrus aurantifolia Swingle.). M.Sc. (Agri.). Thesis submitted to M.K.V, Parbhani.

Tripathi, P. C. and Karunakaran, G., 2013. Bharat Mai Navaneet Phal (Avocado) Ki Kheti: Varthamansthithievam Sambhavanaye (InHindi) (Avocado cultivation in India: Present status and possibilities) Bhumi Nirman (Bhopal) 16th Jan -15th Feb: 11.

Venkatrao, andReddy, Y. T. N., 2005. Effect of osmopriming on germination, seedling growth and vigour of mango (Mangifera indica L.) stones. Karnataka J. Hort. 1(4): 29-35.

Wanyama, D. O., Wamocha, L. S. and Ssnokko, R, N., 2006. Effect $\mathrm{GA}_{3}$ on growth and fruit yield of greenhouse grown Cape gooseberry. African J. Crop Sci. 14(4): 319-323.

\section{How to cite this article:}

Nangialai Hakimi, B. S. Shivakumar, D. Lakshmana, M. Ganapathi and Nagarappja Adivappar. 2020. Effect of Plant Growth Regulators and Chemicals on Seed Germination, Vigour Index and Mortality of Avocado (Persea americana Mill.). Int.J.Curr.Microbiol.App.Sci. 9(08): 3640-3645. doi: https://doi.org/10.20546/ijcmas.2020.908.419 